\title{
Research on the Incentive Mechanism of Grass-roots Employment of College Graduates in Henan Province under the Background of Central Plains Economic Zone
}

\author{
Weiping Guo \\ Zhengzhou Vocational Technical Institute, Zhengzhou, Henan, 450121
}

\begin{abstract}
Keywords: College Graduates; Grassroots Employment; Incentive Mechanism
\end{abstract}
\begin{abstract}
In order to promote the construction of Central Plains Economic Zone and to alleviate the employment pressure of college graduates in Henan Province, we must vigorously promote the employment work of college graduates at the grassroots level. From two aspects of graduates grassroots employment incentive mechanism-the incentive main body includes the government, universities, grass-roots units; and incentive object refers to college graduates, the paper makes analysis and proposes that the incentive main body, including the government, universities, grassroots units should guide college graduates to work in the grassroots actively; guide and educate encouraged object to establish a correct view of employment, with a view to establish reasonable and long-term grassroots employment incentive mechanism of graduates.

With the popularization of higher education, the number of college graduates in Henan Province in recent years enters into geometric growth, and in 2016, the number of college graduates of Henan Province has reached 510,000. The employment situation of college graduates in Henan Province is grim, and only active guidance and motivation for grassroots employment of the graduates in Henan Province can slow down the employment pressure in Henan Province, transport more talent to the rural grassroots, so that more talents can take root in the rural areas and grassroots, promote the development of new countryside, and the fast and good construction of Central Plains Economic Zone.
\end{abstract}

\section{The Status Quo of Grassroots Employment of College Graduates in Henan Province}

First, the number of graduates working in the grass-roots is far from enough, talents "don't come", cannot meet the needs of grass-roots construction. According to the Annual Report on The Employment Status of College Graduates in Henan Province in 2015 issued by Research Group of Employment Quality of College Graduates in Henan Province, the total number of college graduates in Henan Province in 2015 was 499,000, among which the graduates went to the grassroots accounts for about $1.78 \%$, and the quantity is far from enough, accounting for only two percent of the total number of graduates. Henan Province is a large agricultural province, the new rural construction and Central Plains Economic Zone construction require a lot of talents to contribute their talents in the rural area, especially grassroots education, health care, agriculture, management and other aspects need a large number of college students, therefore graduates should be encouraged to join the grassroots construction.

Secondly, the grass-roots staff resignation rate is higher, and the grassroots "unable to retain." According to the relevant data survey, when the service period of college graduates in the grass-roots expires, only less than $10 \%$ of college students are willing to continue to stay, and most of them select to go to the economically developed areas. Although some students choose the grassroots area, but due to the hardships of the grassroots conditions and poor treatment conditions, most of them are reluctant to continue the work when the service period is expired, the loss rate is serious.

Finally, working attitude of students working in the grassroots is not active, "useless". When some graduates just come to the grassroots, their working attitude is positive and very enthusiastic, but because they do not understand of the local folk customs, cannot grasp the working methods, lack of social practice ability, the local farmers and grassroots units are dissatisfied with them on the contrary, which dampens the enthusiasm of the students. As time passed, they work negatively and 
slowly and have no work enthusiasm.

\section{The Grassroots Employment Incentive Mechanism of College Graduates in Henan Province has Problem}

The purpose of constructing the grass-roots employment incentive mechanism for college graduates is to better guide the graduates of the university to go to the grass-roots to work, to better take root in the grassroots and serve the grassroots, to promote the modernization of agriculture and new rural construction, but the overall situation of current college graduates working in the grassroots is not ideal, constituting two main aspects of the incentive mechanism- incentive main body and incentive object have some problems.

Problems in the Incentive Main Body. The main body of the incentive mechanism refers to the executors of incentive measures and the policy. The main body of college graduates grass-roots employment mechanism includes government, universities and grass-roots units. The main body of the incentive plays leading, training, adaptation and other functions. Currently, the main body of incentive, including government, universities, and grass-roots units should assume the main functions together. And now the situation is to emphasize the government-led. Colleges and universities and grass-roots units haven't undertaken the role of incentive main body. The incentive system of colleges and universities and grass-roots units is not perfect.

1. In the incentive of graduates working in the grassroots, government has been always dominant. With the development of Henan Central Plains Economic Zone, in order to better promote the employment of college students in Henan Province working in the grassroots, slow down the employment pressure of college graduates in Henan Province and promote the rapid development of new rural construction and economy in Henan Province, Henan Province Party Committee and Government have introduced a series of policies, clearly encouraging college graduates go to the urban and rural grassroots area to work. In accordance with the actual situation, Henan province government set up a "plan of Henan Province college students' volunteer service in poor counties", "Henan Province rural health personnel construction 51111 project" grass-roots service project, broadening the grassroots employment channels of Henan province college graduates.

2. There are problems for colleges and universities in the educational philosophy, major settings and employment guidance. China's educational philosophy has always had education inertia thinking of elite talent. The cultivation of students and education emphasize the elite talent. In the major settings, the lack of educational philosophy results in the major settings and construction of colleges and universities are out of the actual social needs, especially the major settings do not match the grassroots positions, resulting in a considerable part of the students who want to go to the grassroots cannot find suitable work, thus their enthusiasm is not high. In the employment guidance, there are also problems in colleges and universities. In the employment guidance, most of them only focus on employment information collection, collation and release. The ideological education involved in is less and the grass-roots employment orientation is not clear, lacking of grass-roots employment policy advocacy.

3. The incentive, education, training system of grass-roots units for the grass-roots employment of college students is missing, leading to the grassroots college students' enthusiasm is not high. The grassroots conditions are more difficult, and the income is not high. Many college students want to contribute their own efforts to promote the construction of new countryside, but because they do not have practical work experience or know the local customs and the mentality of farmers, coupled with the village cadres' support are small, so their work efficiency is not high, affecting their enthusiasm. And some students find the deviation between the grass-roots work and their own volunteer, seriously dampening the enthusiasm of their work.

The Object of Incentive. The incentive object of grass-roots employment refers to the college graduates, and working in the grass-roots is mainly determined by the employment concept and values. Because in decades higher education in China focus on the model of cultivating elite talent, resulting in the whole society, including colleges and universities, families, students personal and social media think that college graduates should go to the party and government offices, institutions 
and other "iron rice bowl" to work, which leads to a considerable part of the college students are willing to go to large cities, economically developed areas, including the students from economically backward areas and rural areas. They think it's a waste of their own qualifications, time if go to the grassroots area or the economy backward area. In the survey of grass-roots employment motives, nearly half of the students take grass-roots employment as their own springboard and the channel for politics.

China's high school education model emphasizing theory and neglecting practice results in many students only focus on performance, lack of operational abilities and their social communication skills are poor, so even some students go to the grassroots, it's difficult to use their own school knowledge in the actual application. They cannot communicate with the local people and the grassroots units' leadership freely, and their work is not smooth, resulting in psychological gaps and dampening their enthusiasm.

\section{Countermeasures to Improve the Grassroots Employment Incentive Mechanism of Henan University Graduates}

Improve the Main Function of the Incentive Mechanism. Henan province government should continue to strengthen the government policy guidance, in particular, establish the follow-up protection system for college students at grassroots level and design well from the top level. The government should study the policy of college graduates grassroots employment, especially the follow-up guarantee policy. Henan province is a large population, large agricultural province, so doing a good job of college graduates grassroots employment has far-reaching significance for the slowdown of employment pressure, promoting the economic construction of Central Plains Economic Zone. Henan provincial government should develop more innovative grassroots projects, broaden the grassroots college graduates employment channels based on their actual situation, and earnestly supervise and implement the preferential policies of grass-roots employment.

It is very important to improve the follow-up security system of grass-roots employment. Some students do not want to go to the grassroots, because they worry about facing the employment problem once the service expired, therefore, a considerable number of students have concerns. The government should further introduce relevant policies to place college graduates who working in grass-roots. For example, more students in Henan province are from the rural areas, in order to better guide students to work in the grass-roots areas, this part of students can be "targeted enrollment" to achieve "rural - urban - rural" return.

Colleges and universities should adjust the major settings, carry out grass-roots employment guidance education and strengthen the students' social practice ability.

For the difference between majors and actual work in grassroots employment, colleges and universities should adjust the major settings and make the major structural reform, so that the majors can be set to meet the basic needs of the grassroots areas, especially for some more professional and urgent majors. For the grassroots-related majors, such as education, health care, agriculture, especially agriculture major, colleges and universities should pay more attention to the research on grass-roots work and the adaptability of majors.

Colleges and universities should promote grassroots employment and education through the campus network, radio, microblogging, WeChat and other forms, to guide and encourage students to actively participate in the grassroots work. The ideological and political theory courses and career guidance, career planning courses and other courses in colleges and universities should guide students to establish employment concept and values of grass-roots service, rooting in the grass-roots, and out of hedonism, money worship and other ideas. Colleges and universities should actively guide students' practice ability, organize students to go to the grassroots areas for active exercise in holidays, participate in social practice, in order to enhance communication and hands-on practice.

Henan grass-roots units should improve the long-term employment mechanism

Grass-roots employers should play subjective initiative in the use of graduates, breaking the old ideas of "waiting, depending, requesting", and try to encourage graduates to the grass-roots units for 
employment, to actively contact with colleges and universities and establish long-term cooperation mechanism. For some of the graduates already went to the grassroots area, for their poor operational ability, lack of work experience, poor communication and communication aspects, pre-work training and education and establishment of qualified and transparent promotion channels are needed, so that outstanding students can further grow and develop. Secondly, the grassroots units should also strive to put the treatment in place, so that grassroots employment college students' life can be guaranteed, and they have no worries, can put the whole body on the grassroots work and "stay".

Guide and Educate Henan University Graduates to Establish a Correct View of Employment. Colleges and universities should educate students to establish the correct values and the concept of employment. The education of students cannot just stay in the textbooks and the classroom, and it should be remembered, so that students understand the combination of personal ideal and social needs can truly reflect their own value. They should use long-term development perspective of grass-roots employment in the vast rural areas to display their talent, combining their knowledge and grass-roots needs, to promote the construction and modernization of agriculture. The whole society and the family should also educate college students to be down to earth, develop hardships and good character, and exercise their own character at the grassroots level, to enhance their overall quality and recognize they can achieve career success in grassroots areas.

In short, the establishment of Henan province college graduates grass-roots employment incentive long-term mechanism, the whole society should work together to enable college graduates make achievement in the grassroots, to promote the development of Central Plains Economic Zone.

\section{References}

[1] 2015 Annual Report on the Employment Status of College Graduates in Henan Province. http://www.hnbys.gov.cn.

[2] Notice on Doing A Good Job in 2014 College Graduates Employment And Entrepreneurship Work (Henan Government Office〔2014〕 81), Henan Provincial People's Government Office

[3] Li C.F. . Incentive Theory Research [M]. Shenyang: Liaoning University Press, 2004

[4] F. Kong, Long-Term Mechanism for Establishment of Leading College Graduates to The Grass-Roots Employment [J] Chinese College Students Employment, 2008 (12)

[5] Q.R. Huang. Countermeasures and Thinking on Perfecting the Grass-Roots Employment Guidance Mechanism of College Students [J]. Ideological and Theoretical Education, 2015 (4). 